\title{
CROP LIVESTOCK INTEGRATION FOR MAHAWELI SYSTEMS B \& C
}

\author{
A.B.P.A. BANDARA AND A.S.B. RAJAGURU \\ Department of Animal Science, University of Peradeniya, Peradeniya.
}

(Date of receipt $\quad: \quad$ 05th September 1991)
(Date of acceptance $:$ 11th March 1992)

\begin{abstract}
One hundred and twenty eight farmers in Mahaweli Systems B and C were surveyed, regarding the use of farm labour, farm power and fertilizer in crop production, livestock feeding, and economics of crop and livestock productions. An average crop farmer earned Rs. 27,670 each year from his 1.0 ha of paddy land and from subsidiary food crops grown in 0.4 ha highland. For this cultivation, he had to spend Rs. 5126 and 2220 respectively, for tractor hire and purchase of chemical fertilizers. The annual production of 7.2 tons of paddy straw and the residues of the subsidiary food crops were wasted. The farm labour was idle for about three months every year and the anumal product consumption of the family was found to be low.

With a planned crop livestock integration, every farmer could keep three cattle or buffaloes or fifteen goats in his farm. Full integration of crops and livestock requires stall feeding of livestock with urea-treated straw, upland crop residues, tree legumes, and rice mill feed. Raising of Indian breeds or their crosses rather than the indigenous cattle seems to be the best proposition to obtain full benefits of the integration. Such a farming system would enable the farmer to save the tractor and fertilizer costs, and provide additional income by the sale of milk and calves and hiring out draught animals. This farming procedure would result in an increase of gross farm profit. Efficient use of crop residues, idle farm labour and idle land could be considered as indirect benefits of this integrated system.
\end{abstract}

\section{Introduction}

In Mahaweli Systems B and C, the major emphais presently is on crop production. Yet some settlers own livestock and receive a considerable portion of their income from this source. ${ }^{1}$ Most livestock graze on indigenous grasslands and receive little improved management. This is not surprising hecause 1.0 ha out of the 1.4 ha allocated to each settler is an irrigated paddy land. On the remaining 0.4 ha, livestock has to compete with upland crop production. Thus crop damage by livestock is a problem often faced by the farmer. ${ }^{2}$

Draught power from livestock is a more appropriate choice for small holders. In addition to draught power, livestock provide animal protein and manure. They can efficiently use also the crop residues available on-farm. This is the essence of integrated farming. ${ }^{3}$ There are other spin-offs from integrated farming, including off-season employment, reduced inorganic fertilizer use and spreading risk across several farm enterprises. ${ }^{4}$ 
The objective of the present study was to assess the current level of crop livestock integration in Mahaweli systems B and C. Based on the results obtained, an improved crop-livestock integrated system is proposed with the object of increasing the farm income.

\section{Materials and Methods}

Mahaweli project System B covers an area of 130,000 ha in the districts of Polonnaruwa, Batticaloa and Ampara. ${ }^{5}$ System $C$ is in the dry-intermediate zone boundary with a total area of 69,150 ha. This system includes the districts of Badulla, Polonnaruwa and Ampara. ${ }^{6}$

Of the six zones in system B, the settlement activities have been completed in zones 1,2,3 and 4. A block from each of this zone was selected for this study. There are six zones in System C. Zone 1 is well developed and the activities are controlled by the Department of Agriculture. Settlement in zones 5 and 6 :s incomplete. Therefore two blocks in zone 2 and one each in zones 3 and 4 were selected for the study.

A field survey was conducted during March to May 1988 among 64 farmers from each system. The farmers were randomly selected as follows: four blocks from each system, four units from each block and four farmers from each unit. Farmers were interviewed for obtaining information on family composition, availability of farm labour, land use patterns, ownership of livestock, feeding and management practices, and productivity of crop and livestock.

\section{Results and Discussion}

Each farmer in Mahaweli systems B and C, owns 1.0 ha of lowland and $0.2-0.4$ ha of highland. Lowlands are used for paddy cultivation during both seasons, while the highlands are cultivated with chillie, vegetables, maize and pulses during the Maha season. Almost $65 \%$ of the farmers leave their highlands fallow during the Yala due to the low rainfall.

More than two-thirds of the farmers in the area grow only the crops. Only about a third keep a few livestock in their farms. Crop monoculture in the majority of the Mahaweli farms has lead to several problems. These include poor family nutrition (since these households do not produce any type of animal products such as milk, meat or eggs), high expenditure on tractor power (Table 1), high expenditure for chemical fertilizers (Table 1), and risk associated with crop monoculture. In addition to these problems, farm resources are also wasted under crop monoculture. More than 7.2 tons of paddy straw and considerable amounts of upland crop residues produced in the farm are destroyed annually by burning. The areas of the farm land which are not used for crop cultivation are left fallow and the family labour is idle for about three months every year. In order to improve the living standards of the farm 
families, these resources should be used in an efficient manner. Crop livestock integration could prove a useful proposition in this context. If livestock is introduced to the farms, the crop component and the livestock component will function complementary to each other and the farmer would be able to use this combination to enhance his family income and nutritional status.

Table 1: Cost and returns of a farm having a crop monoculture in Mahaweli Systems B and C

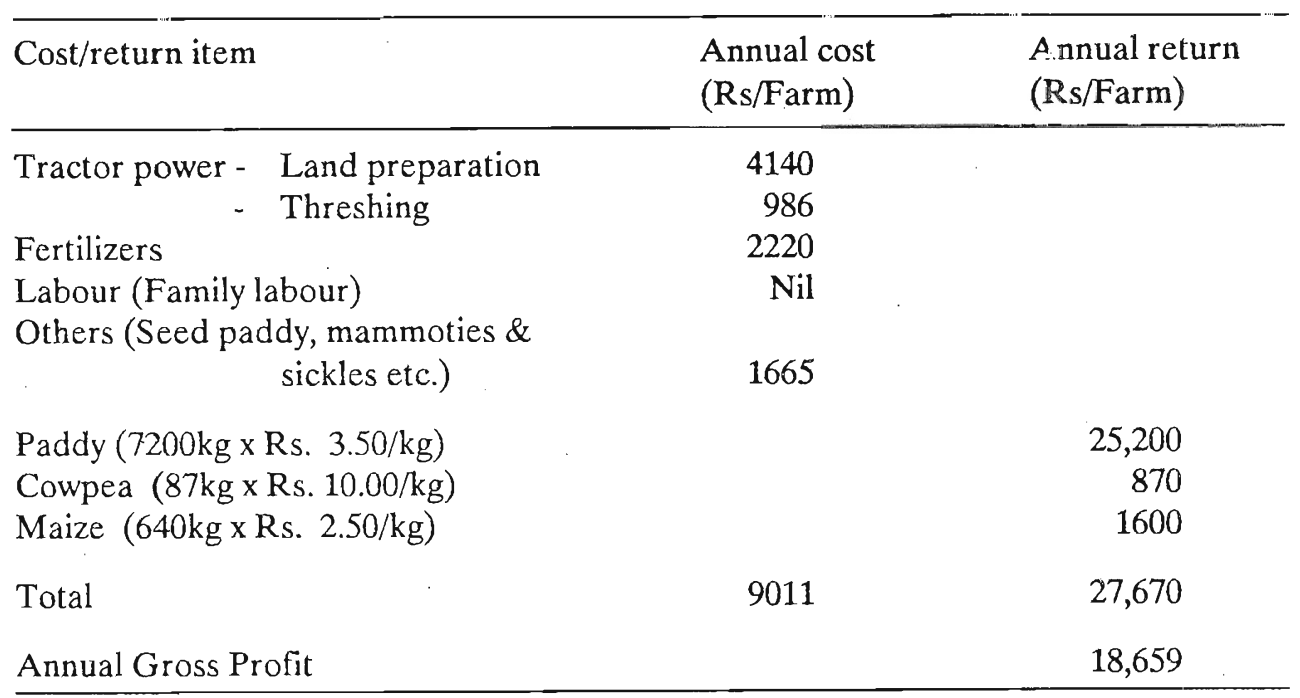

\section{Livestock feed status}

The major constraint to the introduction of livestock into farms is the inadequacy of animal feed. Most farmers are not willing to introduce livestock since there is inadequate land to produce forage.

However, according to the alternative feeding programme suggested by Bandara ${ }^{7}$ every farmer in this area is known to have access to feed materials adequate for three cattle or buffaloes or fifteen goats in his farm. This programme consists of the following: conserving the annual yield of 7.2 tons of paddy straw and feeding them for three cattle or buffaloes after urea treatment, at the rate of $6.57 \mathrm{~kg} / \mathrm{animal} / \mathrm{day}$, maintaining $600 \mathrm{~m}$ long Gliricidia or Leucaena hedges to produce an year round supply of tree legumes for three animals at the rate of $3.5 \mathrm{~kg} / \mathrm{animal} / \mathrm{day}$, obtaining additional herbage by planting improved grasses and pasture legumes at the road sides, paddy bunds and boundaries, using even small amounts of upland crop residues whenever they become available, purchasing locally available rice mill feed for feeding the animals whenever any of above feed materials is in short supply, and practising stall feeding with those feedstuffs. 


\section{Crop livestock integration and farm income}

The annual income of farms having crop monoculture was about Rs. 27,260 and the annual gross farm profit was Rs. 18,659 (Table 1). Meanwhile the farms which had livestock in addition to the crops were able to earn additional income by selling milk and calves (Table 2). These farms were also able to cut down the annual land preparation cost of Rs. 4140 by using their own draught animals. The annual gross profit of these farms was Rs. 24,160 per farm.

Table 2: Cost and returns of a farm having both crops and livestock in Mahaweli Systems $B$ and C

\begin{tabular}{|c|c|c|}
\hline Cost/return item & $\begin{array}{l}\text { Annual cost } \\
\text { (Rs/farm) }\end{array}$ & $\begin{array}{l}\text { Annual return } \\
(\mathrm{Rs} / \mathrm{farm})\end{array}$ \\
\hline \multicolumn{3}{|l|}{ CROPS } \\
\hline $\begin{aligned} \text { Tractor power - } & \text { Land preparation } \\
- & \text { Threshing }\end{aligned}$ & $\begin{array}{l}\mathrm{Nil} \\
986\end{array}$ & \\
\hline Fertilizers & 2220 & \\
\hline Labour (Family labour) & $\mathrm{Nil}$ & \\
\hline Others (From Table 1) & 1665 & \\
\hline Paddy $(7200 \mathrm{~kg} \times$ Rs. $3.50 / \mathrm{kg})$ & & 25,200 \\
\hline Cowpea (87kg x Rs. $10.00 / \mathrm{kg})$ & & 870 \\
\hline Maize $(640 \mathrm{~kg} \times \mathrm{Rs} .2 .50 / \mathrm{kg})$ & & 1600 \\
\hline \multicolumn{3}{|l|}{ LIVESTOCK } \\
\hline $\begin{array}{r}{\text { Cost for } 3 \text { calves }^{\mathrm{a}}}^{+}+\text {interest } \\
\text { for loan }\end{array}$ & 303 & \\
\hline Others (Ropes, drugs etc.) & 675 & \\
\hline \multicolumn{3}{|l|}{ Draught power ( 2 bulls- } \\
\hline Milk $^{\mathrm{b}}(1.5 \times 200 \times$ Rs. 5.30$)$ & & 1590 \\
\hline Calves ( 1 calf/year) & & 750 \\
\hline Total & 5849 & 30010 \\
\hline Annual Gross Farm Profit & & 24140 \\
\hline
\end{tabular}

a - Breed of cattle - Indigenous; productive life - 8 years; Price of a calf - Rs. 750 ; interest rate/year - $8 \%$;

b - Price of milk - Rs. 5.30/Litre; lactation period - 200 days; daily milk production of a cow - 1.5 litres, no. of animals/farm - 3 . 
Poverty is a problem among the farm families in the survey area, since the farm income was low. A crop-livestock integrated system is therefore proposed as an alternative to the existing farming systems. With a feeding programme discussed above, three cattle (or buffaloes) or fifteen goats could be reared in a farm. Indian cattle and buffalo breeds and their crosses are recommended.

If three cattle (or buffaloes) are planned, raising two cows with one bull seems more profitable than one cow with two bulls (Table 3). However if the farmer is unable to exchange a bull with a neighbour for land preparation, keeping two bulls with a cow would be a better option. In this case, it will be possible to obtain income by hiring out this pair of bulls for draught power, in addition to the sale of milk and a calf from one cow.

If the farmer is able to exchange a bull with a neighbour, one bull with two cows are recommended for the farm. Herein the animal power is available only for the farmer's own land, but the milk production and the number of calves born each year will double.

Gross profit per farm will increase under the proposed farming system since a planned integration is envisaged. The total gross profit (from both crops and livestock) of farmers having two bulls and a cow will be Rs. 30,188 (Table 3). This is $62 \%$ higher than that of the present crop cultivators. In farms with two cows and a bull, the total gross profit will be Rs. 33,438, and this in general is $79 \%$ higher than that of the crops-only farmers.

\section{Crop - stock integration and family nutriction}

The farmers are highly dependent on starchy food-stuffs like rice and maize. Pulses such as cowpea, green gram and black gram are the only sources of protein in their diets. Consumption of animal products is very low since the majority of farmers do not have any kind of livestock and they do not have purchasing power to buy these products.

Of the three animals raised in the proposed integrated system, one or two could be cows. If the Sahiwal or Tharpakar cows could be raised in the farm, at least 900 litres of milk yield could be obtained annually. This could automatically improve the nutritional status of the farmer. Futhermore, a few eggs could also be produced by incorporating a few chicken into the integrated system. 
Table 3: Economics of the proposed crop - livestock integrated farm

\begin{tabular}{|c|c|c|c|}
\hline \multirow[t]{2}{*}{ Cost/return item } & \multirow[t]{2}{*}{$\begin{array}{l}\text { Annual cost } \\
\text { (Rs/farm) }\end{array}$} & \multicolumn{2}{|c|}{$\begin{array}{l}\text { Annual return } \\
\text { (Rs/farm) }\end{array}$} \\
\hline & & $\begin{array}{l}2 \text { cows \& } \\
1 \text { bull } \\
\text { system }\end{array}$ & $\begin{array}{l}1 \text { cow \& } \\
2 \text { bulls } \\
\text { system }\end{array}$ \\
\hline \multicolumn{4}{|l|}{ CROPS } \\
\hline Tractor power & $\mathrm{Nil}$ & & \\
\hline \multicolumn{4}{|l|}{ Fertilizers $(1 / 10$ th fertlizers are } \\
\hline replaced by manures) & 2000 & & \\
\hline Others (From Table 1) & 1665 & & \\
\hline Paddy $(7200 \times 3.50 / \mathrm{kg})$ & & 25,200 & 25,200 \\
\hline Cowpea $(87 \mathrm{~kg} \mathrm{x} \mathrm{Rs.10.00/kg)}$ & & 870 & 870 \\
\hline Maize（640kg x Rs. $2.50 / \mathrm{kg}$ ) & & 1600 & 1600 \\
\hline \multicolumn{4}{|l|}{ LIVESTOCK } \\
\hline 3 calves + interest on loan ${ }^{a}$ & 607 & & \\
\hline Drugs \& ropes etc. & 750 & & \\
\hline \multicolumn{4}{|l|}{ Urea for pretreatment } \\
\hline$(288 \mathrm{~kg} \times$ Rs. $3.50 / \mathrm{kg})$ & 1000 & & \\
\hline Facilities for straw storage & 750 & & \\
\hline Milk $^{b}$ & & 9540 & 4770 \\
\hline Draught bull hired outside & & Nil & 3020 \\
\hline Calves sold (1500/calf) & & 3000 & 1500 \\
\hline Total & 6772 & 40,210 & 36,960 \\
\hline Annual Gross Profit & & 33,438 & 30,188 \\
\hline \multicolumn{4}{|l|}{ Profit increment } \\
\hline $\begin{array}{l}\text { - over "crops only" farmers } \\
\text { - over farmers owning both }\end{array}$ & & $79 \%$ & $62 \%$ \\
\hline crops \& livestock & & $38 \%$ & $25 \%$ \\
\hline
\end{tabular}

a - Breeds - Indian breeds or their crosses; Price of a calf - Rs. 1500 ; productive life 8 years; interest rate on loan/year $-8 \%$;

b - Milk production - 4.5 lit/day; price of a calf - Rs. 1500; productive life of a cow - 8 years 


\section{Crop - stock integration and farm power}

The farmers who owned draught animals used them for land preparation. However, the farmers having no draught animals had to depend on tractors for farm power. They spent about Rs. 4,140 for land preparation and Rs. 986 for threshing the harvest ${ }^{-}$ every year. This was found to be a major item that increased the farm costs of Mahaweli farms (Table 4). Of the three animals raised in the proposed farm, one or two may be draught bulls. The cost of farm power in crop production could, therefore, be saved by using these bulls for draught.

Table 4: Cost of farm power (Rs/year) in Mahaweli systems B and C

\begin{tabular}{|c|c|c|}
\hline & System B & System C \\
\hline \multicolumn{3}{|l|}{ Tractor nower } \\
\hline \multicolumn{3}{|l|}{ Cost of land preparation } \\
\hline Two wheel tractor & 4666 & 3800 \\
\hline $\begin{array}{l}\text { Four wheel tractor } \\
\text { Cost of threshing }\end{array}$ & 4500 & 3800 \\
\hline Four wheel tractor & 501 & 485 \\
\hline \multicolumn{3}{|l|}{ Animal power } \\
\hline Cost of land preparation & 2485 & 3580 \\
\hline
\end{tabular}

\section{Crop - stock integration and fertilizer use}

Almost all the farmers purchased chemical fertilizers for their paddy and other crops. They used Basal, Urea, and TDM fertilizers spending about Rs. 2220 every year (Table 5).

Manure production of about 2.4 tons could be obtained from three cattle or buffaloes in a proposed crop - livestock integrated farm. It is recommended to apply animal manure to paddy fields either in fresh form or as compost. It is further recommended to use the crop residues and tree legumes produced in excess of the need for animal feeding, for the manuring of crops. Under the proposed system, if organic manures are used properly, at least $10 \%$ of the annual chemical fertilizer cost could be saved. 
Table 5: Use of fertilizers in Mahaweli systems $B$ and $C$

\begin{tabular}{lccccc}
\hline Fertilizer type & \multicolumn{2}{c}{ System B } & & \multicolumn{2}{c}{ System C } \\
\cline { 2 - 3 } & $\begin{array}{c}\% \\
\text { Farms }\end{array}$ & Amount (kg/ha) & & $\begin{array}{c}\% \\
\text { Farms }\end{array}$ & Amount (kg/ha) \\
\hline Basal & 93.8 & 130 & & 90.6 & 132 \\
Urea & 100.0 & 105 & & 96.9 & 96 \\
TDM & 100.0 & 138 & & 96.9 & 139 \\
\hline
\end{tabular}

Crop - stock integration and the risk associated with crop monoculture

The risk caused by pests, diseases and drought is higher when cropping alcne is practised. A crop failure would have serious effects under the existing system, since most of them are crop oriented. In the proposed integrated system, the effect of crop failures could be compensated to some extent, since the farmer would still be able to obtain some income from the livestock. The livestock in the farm would also be a liquid asset for the farmer in times of financial needs.

\section{Crop - livestock istegration and intensive ase of farm labour}

Under the existing farming systems in the are 2 , the farm labour is idle for about $3-3.5$ months every year. This idle labour could be employed in the proposed type of integrated farm for the feeding and management of livestock.

\section{Limitations for crop - stock integration}

\section{Lack of productive breeds}

More than $50 \%$ cattle and $93 \%$ buffaloes in Mahaweli systems $\mathrm{B}$ and $\mathrm{C}$ belong to indigenous types. The daily milk yield of an indigenous cow was i. 5 litres and that of an indigenous buffalo was 0.7 litres. ${ }^{7}$ This low productivity is a contributory reason for the low preference for livestock among Mahaweli farmers.

It is therefore necessary to introduce productive breeds which are adapted to thie environmental conditions of the area. Indian milk breeds, such as Sindhi, Sahiwal and Tharpakar, and their crosses with European breeds and draught breeds such as Killari and Kangayam can be recommended. Surthi and Murrah and their crosses with Indigenous buffaloes are the suitable buffalo breeds.

\section{Poor livestock extension and veterinary facilities}

The majority of the farmers in the area was unaware about improved methods of livestock feeding. Large numbers of farmers have not evea heard about the possibility 
of using urea treatment technique to improve the feed value of straw (Table 6). This is mainly because of the poor livestock extension service in the area and the focus of extension personnel on crop activities. Veterinary services in the area were also ineffective. Only the farmers in zone 2 of system $\mathrm{C}$ were getting a satisfactory veterinary service. Farmers in the other zones of systems $B$ and $C$ received little or no assistance from the government livestock farms ard veterinary service. Therefore, it is clear that the veterinary as well as livestock extension facilities in the area should be improved in order to obtain the full benefits of crop-stock integration.

Table 6: Farmer's knowledge of the possibility of using urea pre-treatment for improving the feeding value of paddy straw

\begin{tabular}{lcc}
\hline & \multicolumn{2}{c}{$\%$ Farmers } \\
\cline { 2 - 3 } & System B & System C \\
\hline Use & 62 & 34 \\
Not known and not practised & 38 & 66 \\
Known but not used & 00 & 00 \\
Known and used & & \\
Reasons for non-use & & 98 \\
Lack of knowledge & 26 & 25 \\
Lack of capital & 16 & 18 \\
Lack of storage facilities & & \\
\hline
\end{tabular}

At present, the majority of farmers in Mahaweli systems B and C does not raise livestock because of inadequate land to obtain fodder. No systematic crop livestock integration currently exists in these farms. The following recommendations are suggested for a planned integration of Mahaweli farms and to improve their incomes.

1. Introduction of livestock into the farms: three cattle (or buffaloes) of fifteen goats.

2. Effective utilization of all crop residues, planting live fences with tree fodders, growing improved grasses and pasture legumes in the uncultivated areas of the farm and stall-feeding of livestock with these feedstuffs.

3. Use of animal power for land preparation and threshing.

4. Use of animal excreta and, crop residues and tree legumes found in excess of livestock feeding as manure for crops. 
For an effective integration of livestock with crops, it is also essential to use the more productive Indian cattle and buffalo breeds or their crosses. If the Mahaweli farms could be integrated as proposed in the study, the annual gross farm profit would increase by $62-79 \%$ over the current levels. It would also enable the farmer to improve his living and nutritional standards.

\section{Acknowledgement}

This study was funded by the Overseas Development Administration (ODA) of the United Kingdom.

\section{References}

1. Keerthipala A.P. (1986). Socio Economic Survey of Hundred Farmers in Mahaweli systems B and C. M. Phil. Thesis. Postgraduate Institute of Agriculture, University of Peradeniya, Peradeniya.

2. Blauw H. (1984-1986). Livestock production in System $\mathbf{H}$ and final report of the Livestock Extension Project. Sir Lanka - Netherlands Livestock Development programme, Mahaweli Authority, Colombo, Sri Lanka.

3. Rajaguru A.S.B. (1986): Field Crops and Livestock Integration in Sri Lanka. In: Integrated Farming Systems. (Eds. H.P.M. Gunasena and H.M.G. Herath). NASSL, Peradeniya, Sri Lanka.

4. Emil Q.J., Perez C.B.JR., \& Calub A.J. (1980). Integration of Animal and Crop Production in South East Asia. Paper presented at the workshop on Feed Composition, Data Documentation and Feeding Systems in the APHCA region. Manila, Philippines.

5. Acres (1979). Maduru Oya Project - Feasibility Report. Min. Mahaweli Dev. and Acres Intl. Ltd., Niagara Falls, Canada.

6. Hunting Technical Services. (1979). System C Mahaweli Development Project: feasibility study. Main Report. Ministry of Lands, Land Development and Mahaweli Development, Colombo, Sri Lanka.

7. Bandara A.B.P.A. (1989). Crop Livestock Integration for Mahaweli Systems B and C. M. Phil. Thesis. Postgraduate Institute of Agriculture, University of Peradeniya, Peradeniya. 